\title{
Ideas About the English Language in Early Technical Writing Textbooks
}

\author{
John Hagge \\ Iowa State University ${ }^{1}$
}

Early 20th-century American technical writing textbooks were addressed primarily to students and practitioners of engineering. The article argues that 12 important textbooks dating from 1911-1930 somewhat paradoxically conflate three different traditions of language use prevalent in America at the time. This conflation occurs because engineers in their dual role as applied scientists and progressivist managers were extraordinarily sensitive to language use. In turn, broader social and intellectual currents in America are used to explain engineers' linguistic concerns, which the textbooks, based on engineering practice, mirror.

ALTHOUGH I HAVE WORKED as a technical writer and editor, and although $I$ have taught technical editing and business communication, my primary academic training has been in languages and linguistics. Currently I teach courses on general linguistics and on the history of English. My scholarly publications focus mainly on how English is used in professional (business, scientific, and technical) documents and on how practitioners, teachers, and theorists have conceptualized the role of language in such texts. This autobiographical information has been included to clarify my approach to this paper, which presents a preliminary account of how certain ideas about language prevalent in post-bellum America were combined and codified in early engineering writing textbooks. These textbooks, which primarily address engineering students and practitioners (Connors, 1982; Hagge, 1995), reflect the preoccupations of the contemporaneous engineering profession

\footnotetext{
This article is a revision of a paper presented as Invited Speaker, Canadian Association of Teachers of Technical Writing, Learned Societies Conference/Congrés des sociétés savantes, Calgary, June 4, 1994. Initial research was done during an lowa State University On-Campus Sabbatical Semester for Study in a Second Discipline, Spring, 1994.
} 
as a whole, mirroring its ideas about technical discourse and about how the engineers' language should project a sense of professionalism, status, and dignity. The textbooks I examine are largely those that Connors (1982) treats in his seminal article "The Rise of Technical Writing Instruction in America."

As Connors (1982, p. 333) remarks, "until the 1950's technical writing and engineering writing were synonymous." Thus, what the textbooks in this study say about engineering writing perforce applies to technical writing as well, and one of my objectives in the larger project (Hagge, 1995) of which this paper is a part is to extend Connors's work by showing how these textbooks institutionalized ideas about technical language already current in professional engineering circles. Textbook authors took great pains to base the discourse conventions they codified on the real-world written work of actual engineers and on writing standards developed by professional engineering societies and promulgated in professional engineering journals, reference books, and style guides (Hagge, 1995). That is, these early textbooks serve as reliable indicators of the profession's conceptualizations of technical language, which, in turn, are inextricably connected to broader trends described by American social and intellectual historians. My project, in sum, analyzes how ideas about technical language were treated for the first time in a deliberate, self-conscious, and principled fashion by the engineering profession that conceptualized, institutionalized, and promulgated them. This treatment of language is reflected in the contents of early 20th-century engineering textbooks, which thus lie at the root of the modern institution of technical communication and which therefore deserve serious examination.

\section{Motivations for the Study}

In my introductory paragraphs, I foregrounded the words "institution" and "institutionalize" for good reason. I intend what I admitted in my opening autobiographical gambit - that I am not part of the contemporary institution of technical communication-to be taken to mean (I hope) that I can look rather dispassionately at my subject. I am conscious of having no axes to grind; I owe no allegiance to any one method of practicing technical communication or to any one school of technical communication theory. I simply am interested in performing a meta-analysis intended to surface some ideas about language use in technical communication and to trace from whence they were derived.

Now, when an investigator wishes to trace ideas about how language is conceived in a certain genre of discourse, two general approaches recom- 
mend themselves. One might collect examples of that discourse type and try to infer from them the principles of their construction and the nature of the ideas about language they presuppose. Or, one might collect and analyze explicit statements made by those who deliberately identity themselves as in some way involved in the production of that discourse type-as writers, editors, or teachers, for instance. At first blush, the former method appears useful and seems empirical. But to my mind it is problematic, especially for the study of technical discourse. For one thing, the genre is notoriously hard to define; an investigator would be hard-pressed to determine what counts as technical discourse and what does not. As will appear shortly, such determinations can create vicious circles. In addition, as those who read or practice literary criticism know, establishing the legitimacy of textual inferences can be hard to accomplish. The second method, which I detail momentarily, has several advantages. First, those who comment on the discourse that they produce already are working in the realm of ideas; no inferential leap between mute texts and the ideas about discourse on which they appear to be based is needed. Second, the ideas being studied have been identified as being about a particular discourse type by the very persons anticulating those ideas: The investigator does not have to decide a priori what does or does not count as an instance of the linguistic ideas being studied. Third, because explicit statements about a discourse type often are licensed by an institution involved in the production of that discourse (for instance, a professional association such as the American Institute of Physics, the American Medical Association, or the Council of Biology Editors [see Hagge, 1994]), and because they have been modified slowly over time in that institutional setting, they transcend individual pronouncements, represent accreted wisdom, and thus have strong validity.

Unfortunately, few if any studies of ideas about American technical discourse done in my second sense exist. In fact, according to some scholars, research on technical communication as a whole has been ahistorical (Brockmann, 1983; Moran, 1985). Although several literature reviews have demonstrated a recently burgeoning interest in the field's history (Brockmann, 1983; Moran, 1985; Tebeaux and Killingsworth, 1992; Rivers, 1994), research on the development of technical communication in America still is comparatively sparse (Rivers, 1994, pp. 45, 55-56). Furthermore, Philip Rubens (1985, p. 15) concedes that in general "technical language has not received a great deal of attention" in work on professional communication (see also Lipson, 1985, p. 143). Therefore, it appears accurate to state that few studies of tech- 
nical communication in America pay explicit attention to the development of ideas about technical language.

It also appears accurate to state that a leading tendency in general historical scholarship to date has been to connect the rise of technical communication with Baconism and the plain-style scientific rhetoric of the Royal Society (bibliographic exegeses are Brockmann, 1983; Broadhead, 1985; Lipson, 1985; Moran, 1985). To trace how technical communication in general has developed in America, numerous writers explore the role of a key figure, who often appears to get connected to this overarching idea of the scientific plain style. The most popular subject in such work is Benjamin Franklin (Brogan, 1965; Gresham, 1977a; Hargis, 1962; Tebeaux, 1981). Other articles treat Cotton Mather (Gresham, 1977b; Schulman, 1963), George Washington Carver (Gresham, 1979), and Albert Einstein (Baresich, 1980). Many people would classify such figures as scientists as well.as, or rather than, technologists; this research thus assumes that technical discourse can be conflated with scientific discourse and can be conceptualized similarly. In addition, some short articles in the "Models for Technical Communicators" section of Technical Communication discuss prototypical American writers whose prose also meets desiderata that supposedly define technical discourse: It is simple, natural, concise, unornamented-in short, "scientific." Featured have been Presidents Grant (Breithaupt, 1991) and Jefferson (Nichols, 1991), novelists Ernest Hemingway (Poulsen, 1990) and Herman Melville (Kilgore, 1981), and submarine inventor David Bushnell (Price, 1988).

The relevant literature, then, leaves the strong impression that the main idea lying behind the development of technical discourse in America is somehow connected to the concept of language in the plain-style, Baconian tradition. It thus tacitly supports the claim of Charles Barber (1976, p. 133), an eminent historian of the English language, that the Royal Society's emphasis on "simplicity, naturalness, clarity, conciseness, [and] a rejection of all ornament . . is an admirable ideal for scientific prose, and indeed for many types of prose discourse," including technical discourse. Moreover, the subjects of these studies appear to have been chosen just because, it is claimed, they communicated using plain-style ideas and techniques. That is, historical research on supposedly exemplary technical writing practitioners relies on the tacit and largely unargued assumption that technical writing and scientific writing may be viewed as largely synonymous and that they are roughly equivalent because both at their core are defined by use of "plain" language. For instance, President Grant serves as a technical writing model because he es- 
poused "plainness in speech" (Breithaupt, 1991, p. 150). Hemingway's "minimalist style" is said to correspond to the "technical communicator's goal...: to avoid burdening...audiences with information they don't need" (Poulsen, 1990, p. 341). Published in a leading journal that represents the present-day institution of technical communication, Batschelet's (1988) study of the influence of the Puritan plain-style sermon on early American science writers again reinforces my contention that this institution now accepts as a tacit but foundational premise an equation between scientific and technical writing the copula of which is the idea of plain language. (This article also ignores the fact that several historians of English prose style have demonstrated connections between Puritanism and the plain style in England well before the era that Batschelet covers [Adolph, 1968; Barber, 1976, p. 77; Fisch, 1952, pp. 245-248].) In short, there is a seeming circularity in extant work on the development of technical communication in America. People and texts are chosen because it is tacitly assumed that they adhere to plain-style norms of scientific communication. Then this use of plain language is cited as evidence corroborating that indeed the person or text does fall into the realm of technical communication.

\section{Thesis and Methods for the Study}

Moreover, studies that fail to differentiate between technical communication and other types of discourse (especially scientific discourse), recently have undergone methodological criticism (Rivers, 1994, p. 46; Tebeaux and Killingsworth, 1992), and the "great man" approach to history exemplified in many of the articles just cited has been deemed a "conceptual error" because "such histories [have] only very obliquely or superficially revealed the true reality of the historical past" (Brockmann, 1983, p. 155). Many articles I have mentioned also restrict the function of technical communication solely to the transmission of information, implicitly adopting the linguistically discredited Conduit Model of communication (Reddy, 1979). However, the authors of the textbooks in my study argue that the language of engineers-which (again) at the time often was referred to as "technical writing" (Connors, 1982; Hagge, 1995) - functions in ways that most of the extant historical research has ignored. I will argue that the selfstyled technical writing conventions developed during the first decades of this century and collected in my sources resulted from engineers' unique position in American society as applied scientists who often became managers of extensive private or public organizations. Because of the social and 
professional pressures these engineers faced, they developed an extraordinary sensitivity to language use. The language that engineers were enjoined to use by their professional societies, by leading practitioners, and by the early textbooks was conceptualized as an amalgam of conventions taken from rather disparate discourse types, not solely as a continuation of the plainstyle, Baconian tradition.

\section{The Intellectual History of the English Language in America}

These discourse types are differentiated in recent work on the intellectual history of the English language in America. The framework for the following discussion derives from Kenneth Cmiel's (1990) Democratic Eloquence: The Fight over Popular Speech in Nineteenth-Century America. Cmiel argues that prior to the rise of popular democracy, public discourse was dominated by the classical ideal, mediated through 18 th-century Neo-Classicism, of the rhetor as gentleman-a liberally educated, virtuous citizen-orator, upper-class if not aristocratic, who maintained civic standards by employing a well-defined public discourse characterized by the use of what linguists would call a high, formal register, a certain degree of impersonality, adherence to established usage conventions, reliance on allusions to canonical literature, and avoidance of technical or professional jargon on the one hand and colloquialisms on the other. Use of refined discourse defined one's character and was produced by a genteel education designed to mold such a character. Various social and intellectual currents undermined this genteel tradition, however. As early as Tom Paine's time, some Americans, impatientwith decorous language, opted for a blunter, plainer public discourse. In addition, the rise in 19th-century America of what Cmiel calls the "middling" class value-system, with its emphasis on social fluidity, demanded a more colloquial and more warmly personal public language. Conversely, academic philologists, the precursors of today's professional linguists, stressed the inevitability of linguistic change, investigated dialectal variation, promulgated the notion that no one form of a language should be privileged, and argued for the acceptance if not precedence of technical vocabularies used by subjectmatter experts, mainly scientists and academics. Cmiel argues, then, that three rhetorics, or general ideas about language, competed for public allegiance in late-19th-century America-what I will henceforth call genteel rhetoric, middling rhetoric, and expert-scientific rhetoric. He isolates two varieties of middling rhetoric, a more colloquial strand and one that pro- 
moted "Saxon eloquence" (pp. 112-120). An analysis of my sources using standard methods from intellectual history will show that their concept of engineering language does have affinities with the idea of Baconian scientific discourse as mediated through expert-scientific rhetoric, but it also features ideas about language use from the Saxon-eloquence and genteel rhetorical traditions. This particular amalgamation of ideas about engineering discourse can be connected to the wider concerns of the developing engineering profession, which in turn can be explained in terms of even broader social and intellectual currents in America.

To understand the subtle, complex conceptualization of language in early technical writing textbooks, I used a method widely employed in intellectual history (Boas, 1969; Greene, 1957/58; Lovejoy, 1936) and looked for motifs - repeating patterns of phraseology and thought—in my sources, 12 important technical writing textbooks published between 1911 and 1930 (starred doubly in the Reference List and hereafter referred to as "Sample Textbooks"). Many of these textbooks are mentioned in the influential studies of Connors (1982) and Grego (1987), and several went through subsequent editions. Most are cross-referenced by other Sample Textbooks as constituting essential reading for the engineers whom they address. Moreover, almost all the Sample Textbook authors had close contacts with the engineering profession. Frost, Gaum, and Rickard were themselves trained as engineers. Baker, Earle, Harbarger, Howell, Naether, and Watt were active members of the Society for the Promotion of Engineering Education (SPEE) and published articles in its journal. The SPEE itself included many prominent practicing engineers as members, as well as professors of engineering and of ancillary areas such as engineering English, mathematics, and mechanical drawing. Aydelotte's reader for engineering students contains essays by some of America's most eminent engineers, such as John Lyle Harrington, John Butler Johnson, and George S. Morison. The Sample Textbooks do appear to reflect the conventions and practices of the emerging engineering profession (Hagge, 1995) and thus are important sources of information concerning the institutionalization of ideas about engineering language.

The dates I chose, 1911-1930, coincide in part with what Connors (1982) has called the "early years" of American technical writing instruction. (For other accounts, see Grego, 1987; Schmelzer, 1977). Connors remarks that no important technical writing textbooks were published before 1908 (p. 332). Because he dismisses Rickard's (1908) $A$ Guide to Technical Writing as "merely a precursor to the first genuine technical writing textbook written 
for use in college courses" and "a transitional text that dealt mostly with usage, meant more for practicing engineers than for college classes" (p. 332), Ibegan my survey with two books published in 1911 (Earle, 1911; Frost, 1911). Two important national reports on engineering education (Mann, 1918; Wickenden, 1930) were written during the 1911-1930 period; using the date of the influential latter report as a terminus ante quem for the present study thus makes sense. Analyzing a dozen sources that span the first 20 years of the institutionalization of technical writing ensures a large, representative data sample. I chose only textbooks explicitly designed to cover technical communication, eliminating those that equally stressed scientific communication (e.g., Allbutt, 1923; Trelease and Yule, 1925). My sources represent a large percentage of the technical writing textbooks published during my time frame, excluding second and subsequent editions. To exemplify the motifs I discovered, I quote frequently from the Sample Textbooks. As my frequent parenthetical citations indicate, such quotations in most cases could be multiplied many times.

\section{Ideas about Language like those in Expert-Scientific Rhetoric}

Because of other historians' pervasive conceptualization of language use in technical communication as influenced by the Baconian plain-style tradition, it might appear reasonable that the development of ideas about technical language in America can be understood solely by linking it to Cmiel's category of expert-scientific rhetoric. Indeed, American expert-scientific rhetoric does have affinities with this tradition, as will appear below, and it does appear to have influenced ideas about language in the Sample Textbooks. But things are not quite so simple. My sources differentiate engineering discourse from other varieties, oddly enough, by undercutting the ideal of straightforward scientific language. That some ambivalence about the use of scientific language occurs in early technical writing textbooks can be explained by making connections to broader developments as analyzed by American social and intellectual historians and by realizing that the development of ideas about technical language in America is more complex than is often assumed.

\section{The Functional Distinctiveness of Engineering Language}

There can be no doubt that authors of the Sample Textbooks viewed engineering discourse as functionally and substantively distinct from other 
contemporaneous types of language use. One of the earliest authors of a technical writing textbook, Samuel Chandler Earle (1911, p. 164), asserts that "Anyone who addresses specialists on a technical subject should use the special language of that particular technic.... Each profession has its peculiar forms of expression and even its individual habits of thought" (original emphasis). Howell (1930, p. 1) makes the same point: "Every profession has a definite style in discourse and a number of professional forms peculiar to itself." In fact, "engineering English differs from the ordinary type of language found in magazines and books in that it usually follows a definite code intelligible to other members of the profession but often meaningless to the layman" (p. 2 [original emphasis]). That engineering language constitutes a distinct linguistic code is emphatically enunciated by Harbarger (1923, pp. 129, $151,154,218$ ) as well. Such a differentiation makes sense in terms of American thought during the period just prior to the publication of the Sample Textbooks, when the idea that technical language should be an important component of American English surfaced and was prominently discussed. The academic philologists who promoted expert-scientific rhetoric celebrated their own expertise, overturned the centuries-old stigma against using technical vocabularies in public discourse, and by the end of the 19th century had made technical talk prominent (Cmiel, 1990, p. 163). By century's end, "specialized languages became celebrated as critical to the nation's health" (p. 261). The philologists played expert, scientific-technical language off against other types (p. 150), particularly that type conceptualized in the tradition of genteel rhetoric, for which specialized discourse was suspect and not part of refined usage (p. 34). The idea that people mightemploy distinctive varieties of English for special purposes was a controversial component of American thought when the Sample Textbooks were published, as was the concomitant idea that varieties of language other than the standard literary one should be considered licit.

Both Howell and Earle, for example, deliberately oppose engineering language to some aspects of the literary language valued in the genteel rhetorical tradition. Readers of belles lettres must adapt themselves to literary compositions; conversely, engineers who write business letters must adapt themselves to their readers (Howell, 1930, p. 175). Earle (1911, p. 224) recommends that "most technical writers avoid...'literary' qualities" when they write, such as picturesque language and rhetorical figures, although he does grant that such literary devices may be used to counteract monotony of presentation. In general, Sample Textbook authors show the same aversion 
to ornate, "literary" language as did earlier proponents of the plain-style tradition (Barber, 1976, pp. 131ff.). But the genteel rhetorical tradition was not altogether renounced in the Sample Textbooks, as it most emphatically was in the tradition of expert-scientific rhetoric (Cmiel, 1990, esp. pp. 148ff.). Moreover, this motif of eschewing ornateness has affinities with the Saxoneloquence movement as well, as will appear below.

Links between the tradition of expert-scientific rhetoric and ideas about language espoused in the Sample Textbooks, then, are not hard to find. I have already yoked the Sample Textbooks' aversion (albeit a tempered one) to literary language with ideas from expert-scientific rhetoric; proponents of expert-scientific rhetoric “distrusted literary language" too (Cmiel, 1990, p. 158). Another connection appears in Aydelotte's (1917) reader English and Engineering, which contains a selection on "The Standard of Usage" by Thomas R. Lounsbury, one of the leading lights among the scholarly philologists who promoted expert-scientific rhetoric (Cmiel, 1990, pp. 14849, 179-180, and elsewhere). Nevertheless, it should be noted that Lounsbury, unlike some of his cohorts, deliberately appeals to a literary standard, that of the "best writers," in this essay (quoted in Aydelotte, 1917, pp. 72-76). Three of the Sample Textbooks, moreover, explicitly mention the idea of simplified spelling, which was integral to the program of expert-scientific rhetoric (Cmiel, 1990, pp. 83-85, 158-161). Frost (1911, pp. 30-33) argues most strongly for the idea, citing Funk and Wagnells' Standard Dictionary of the English Language, a work edited by "leading philologists" (p. 31) of the expertrhetoric school (Cmiel, 1990, pp. 224ff.). Howell (1930, p. 33) also generally favours this linguistic idea, whereas Harbarger (1923, p. 43) argues against the use of simplified spellings because they might offend readers.

Explicit links between the conventions of expert-scientific rhetoric as delineated by Cmiel and the conventions of engineering writing codified in the Sample Textbooks indubitably exist. The most marked affinity relates to vocabulary. Those in the expert-rhetoric camp promoted the idea of professional specialization (Cmiel, 1990, pp. 167-168) and with it the value of professional jargon, the use of which previously in American thought had been considered vulgar (pp. 65, 225-227). Specialist and non-specialist language differs most obviously in vocabulary. As historians of English (Jones, 1953; Barber, 1976; Görlach, 1991) have shown, ever since the English Renaissance, when technical terms derived from Latin and Greek threatened to overwhelm the native English word-stock, a lively debate has centred around the extent to which such terms should be used. Although 19th-century 
American defenders of genteel rhetoric deemed "technical talk ...neither civil or civic," the scholarly philologists "asserted that only technical vocabularies could purchase precision, that specialized vocabularies bore witness to the advance of civilization" (Cmiel, 1990, p. 163). The Sample Textbooks make no bones about acknowledging the value of technical vocabulary in disciplinary work, whereas at an earlier period in America, such a position would have been harder to maintain. Earle (1911, pp. 204-207), for example, who connects the use of technical terminology with the "exact sciences," acknowledges that languages increase their word-stock by the "continual addition of technical terms," but does advocate defining terms unfamiliar to readers (see also Howell, 1930, pp. 3, 275; Baker, 1923, pp. 53-56).

Nevertheless, the Sample Textbooks do not wholly condone use of such specialized terminology as Cmiel (1990, p. 150) shows proponents of expertscientific rhetoric, who argued that "technical vocabularies were the heart of educated language," did. Instead, Sample Textbook authors emphasize using the technical lexicon where contextually appropriate. Naether and Richardson (1930, p. 277), for example, aver that technical terms “are in good use only when appropriate to occasion and context, and when addressed to those who understand them." The "specialist or expert who [takes] report-writing most seriously" works in a profession that "demands not technical skill alone, but the ability to translate his knowledge to fit the understanding of outsiders" (Gaum and Graves, 1929, p. 3). This attitude contrasts with the radical promotion of specialist terminology manifested by the academic philologists, who argued for the wholesale acceptance of expert-scientific rhetoric (Cmiel, 1990, pp. 163-165). The ambivalence toward a specialized engineering lexicon also differs from the tendency in American science from the 1830 s on toward lexical specialization (Curti, 1964, p. 318).

Cmiel (1990) treats only vocabulary specialization in his account of expert-scientific rhetoric. An indication of some Sample Textbook authors' linguistic sophistication is their acknowledgement that linguistic differences other than those related to lexical choice characterize engineering language, which diverges from other types of American English on the whole-discourse level in its employment of typically short paragraphs (Gaum and Graves, 1929, pp. 99-101; Howell, 1930, pp. 81, 91-92; Watt and McDonald, 1925, pp. 54-55), on the morphological level with its characteristic use of compound words (Gaum and Graves, 1929, p. 113; Howell, 1930, p. 131), and on the orthographic level with its tendency to replace words by numerals (Gaum and Graves, 1929, p. 110; Howell, 1930, p. 115) and its self-confess- 
edly idiosyncratic uses of the hyphen and the comma (Howell, 1930, pp. $115,120)$.

It is a commonplace of intellectual history that science and the so-called scientific method were thought (at least until recently) to be objective and impersonal. Objectivity and impersonality have been considered characteristics of technical language as well, presenting a problem for some current theorists (the locus classicus is Miller, 1979; see also Harris, 1982; Gerson, 1988; Rutter, 1991). The Sample Textbooks do indeed reinforce such a characterization, albeit again with deliberate nuancing. Solberg (1929, Ch. 2, pp. 16-24), who compares scientific and technical discourse in his account of "The Characteristics and Kinds of Expository Descriptions," explicitly makes this point: "The scientist must be objective, impersonal, and the expository descriptions which he writes must be impersonal and objective" (p. 17). Howell (1930, p. 108) reiterates this claim: "The first quality of engineering style is impersonality. The writer should look upon himself as a machine, delivering facts clearly, concisely, attractively, but not obtruding his personal bias." His telling metaphor appears strikingly apposite for the era known as the "Machine Age" (Ostrander, 1970). Naether and Richardson (1930, p. 4) concur, opposing "feeling discourse," meant to arouse the emotions, to "thought discourse," which "keeps the emotion-arousing individuality of its author in the background or excludes it altogether." Several Sample Textbook authors, then, state that when addressed to other specialists, engineering language should be impersonal and objective (Gaum and Graves, 1929, pp. 46, 90; Howell, 1930, p. 108; Naether and Richardson, 1930, p. 4; Solberg, 1929, pp. 17, 19), accurate and unambiguous (Earle, 1911, pp. 208209; Gaum and Graves, 1929, p. 88; Howell, 1930, p. 56; Naether and Richardson, 1930, p. 47; Watt and McDonald, 1925, p. 144) and maximally efficient (Earle, 1911, p. 32; Frost, 1911, p. 64; Harbarger, 1923, pp. 59, 211 ; Rickard, 1920, pp. 9-10; Watt and McDonald, 1925, p. 157).

My sources, however, make caveats and introduce distinctions that mitigate the force of these bald notions, demonstrating that ideas about the characteristics of technical language in the Sample Textbooks do not reflect solely the norms of the Baconian plain-style language ideal. For instance, Gaum and Graves (1929, p. 90) agree that engineering "reports are essentially objective and impersonal in tone." But although the text of the report must be kept "impersonal and objective" (p. 14), the letter of transmittal may reflect more of the writer's personality (p. 34). In fact, the business letters that engineers often must write are "informal and personal" because they 
attempt "to establish a close and friendly contact with the reader" (p. 14). McDonald (1929, p. 26) makes the same point:

The choice of form for a report depends somewhat on the writer's personality, but is also influenced by the subject matter, the character of the readers of the report, and the impression that the writer wishes to convey. A formal individual submitting technical facts to a group of readers who are strangers to him is likely to choose a professional, thirdperson style. An informal individual reporting his impressions or observations is likely to choose a conversational, first-person style, particularly if he knows personally the officials to whom he makes the report.

This quotation (and a similar one in Gaum and Graves, 1929, p. 89) manifests considerable linguistic sophistication. The contemporary linguistic term "register" denotes "a variety of language defined according to its use in social situations" (Crystal, 1991, p. 295). Components of register are often identified as field, or subject matter treated; tenor, or degree of formality; and medium, written versus spoken (Gramley and Pätzold, 1992, pp. 35-49). McDonald's quotation is noteworthy because it shows an awareness that technical language must vary situationally according to field and tenor. As appears below, because engineers must interact in a wide range of social situations, they cannot, according to the Sample Textbooks, always use a specialized register but must adapt their discourse to varying audiences.

Arguments in the Sample Textbooks about using passive-voice constructions, much favoured in writing thought to be objective and scientific because it deletes personal agents (for example, Howell, 1930, pp. 77 and 217; Gaum and Graves, 1929, p. 103), demonstrate textbook authors' ambivalence toward blanket adoption of a completely impersonal style and their constant invocation of situational context as the determiner of linguistic choices. Although "some years ago it was commonly assumed by American engineers that they must never write 'I,'” McDonald (1929, p. 15), for instance, believes that "such a rule is too rigid and tends to minimize the human interest" and that "the repeated use of the passive voice is monotonous" (p. 15). Howell agrees. Whereas "the passive voice is much used in engineering writing to give an impersonality to articles and reports" and "is much to be preferred for scientific articles and most accounts of experiments or of work performed," it is "frequently awkward and unnatural" and "less concise than the active voice"; "in letters and in more personal writing it 
should not be used where the active voice is equally effective" (Howell, 1930, p. 163).

That Sample Textbook authors advocate employing "unambiguous" language provides more evidence that they view engineering discourse, especially its lexicon, in partially Baconian terms (Baker, 1924, pp. 53-54; Frost, 1911, p. 45). "The [technical] writer usually possesses a specialized vocabulary... [and] may wish to use terms in a restricted sense, and so to eliminate all possibility of ambiguity by early, if arbitrary, definition" (Gaum and Graves, 1929, p. 58). "As scientific study has become more exact, technical terms are getting to be more carefully chosen and more rigidly used" (Earle, 1911, p. 210). Part of the Baconian project was the development of an immutable variety of English in which each word was designed to denote transparently one and only one thing (Barber, 1976, pp. 135-141; Barber, 1993, p. 203). Hobbes, Locke, Wilkins, and others who wished to create an artificial language free of the ambiguities and other defects of ordinary language did so in order to enhance philosophy and science and to transmit timeless truths (Barber, 1976, pp. 137-141). Nonetheless, the codifiers of ideas about engineering language wished to eliminate ambiguities in everyday transactional, not philosophical, language and buttressed their arguments with pragmatic, particularly legal, considerations.

For example, in technical writing Howell (1930, p. 56) believes that "vagueness is an inexcusable fault. It may even lead to serious trouble if it occurs in legal documents or in letters." Watt and McDonald (1925, p. 144) use similar logic: "Many mistakes and consequent loss of time and money occur constantly in business and engineering because a vague word is used in a letter, a wrong word is used in specifications for engineering work, or even a careless word is uttered in conversation. Many lawsuits arise over doubtful sentences." Gaum and Graves (1929, p. 88) equate linguistic unambiguity and accuracy - "exactness of statement"-with professional practice, with "accuracy in field work or research." The need to use accurate, unambiguous words generally is connected to the pragmatic needs of readers (Earle, 1911, pp. 208-209; Naether and Richardson, 1930, p. 47), not solely to the more abstract requisites of the scientific method. Thus, the Sample Textbooks' perceived need for specialized, standardized vocabularies provides another connection to Cmiel's (1990) account of expert-scientific rhetoric, which stressed creating such vocabularies, vocabularies that typify a "scientific" outlook on language use (Barber, 1993, pp. 215-218).

Other evidence confirms that engineering language was indeed 
conceptualized in the Sample Textbooks as a distinct language variety. The marked tendency toward standardization of engineering language, especially of specialist vocabulary (Baker, 1924, pp. 237, 259-260, 279), suggests that its users considered it distinctive. Constituents of this language variety are codified as formal conventions and promulgated and institutionalized in specialist publications of engineering societies, which textbookwriters often exhort their readers to peruse (Hagge, 1995):

In the use of abbreviations, the engineer should follow the practice of the better engineering periodicals and of the national engineering societies...

Not all scientific and technical terms, especially new ones, can be found in a dictionary. The student should follow the better-edited technical periodicals for such practice and should notice how careful editors write. The national engineering societies of America are an influence for the standardization of technical terms in their numerous publications. (McDonald, 1929, pp. 21, 143. See also Harbarger, 1923, pp. 8, 157; Howell, 1930, p. 19)

Sample Textbook authors also frequently mention style books produced by professional societies and advocate adherence to the linguistic norms established by them. These style books include Suggestions to Authors of Papers Submitted for Publication by the United States Geological Survey (Baker, 1924, p. 434; Watt and McDonald, 1925, p. 149); Suggestions to Authors (American Institute of Electrical Engineers) (Watt and McDonald, 1925, pp. 28, 47); and $A$ Handbook of Architectural Practice (American Institute of Architects); Style Manual for Engineering Authors and Editors (American Society of Mechanical Engineers); and the well-known Manual of Style published by United States Government Printing Office (Gaum and Graves, 1929, pp. 285-286). Howell (1930, pp. 42-43) exemplifies this desire to incorporate the best professional practice and the language norms established by professional engineering societies. In his technical writing handbook, he offers a "brief list of technical abbreviations" that he assures the reader "has been checked against the lists prepared by the American Society of Mechanical Engineers and the Society for the Promotion of Engineering Education, and the style books of several of the technical presses." Important sociolinguistic research has demonstrated that group-fostered language use helps to promote group identity and serves to differentiate outsiders from in-group members (Hudson, 1980; 
Labov, 1972, esp. pp. 1-42). The Sample Textbooks argue that engineers reinforce such a differentiation whenever they use the specialized linguistic code of their profession. That is, linguistic features that characterize engineering discourse are constantly reinforced in engineers' minds as they encounter, through reading or writing, specialist discourse that uses linguistic features specific to engineering. These features are promulgated through professional publications and style guides and through the Sample Textbooks themselves, which repeatedly stress the cardinal idea that engineers belong to a particular speech community (Hudson, 1980, pp. 25ff.; Hymes, 1974, pp. 47-51) that gives them identity and social recognition.

The engineering societies to which the Sample Textbooks refer many times (Hagge, 1995) were of the utmost importance in a practicing professional's life. Why this should be so appears from a brief analysis of broader historical trends. Even as early a commentator on American mores as Alexis De Tocqueville mentions Americans' proclivity for joining a myriad of private associations (Bates, 1965, p. 37). Professional societies took on an even greater significance for Americans of the Machine Age, and these societies influenced the "standardization of nomenclature and the development of specialized bibliographies" (Daniels, 1971, p. 270; see also Curti, 1964, pp. 317-318). Therefore, the Sample Textbooks' emphasis on the uniqueness of the engineering lexicon, which the publications of engineering societies also employ and officially sanction, accords with a more general American historical trend. According to one influential account of the rise of technology in America, creation of engineering societies was motivated by engineers' desire to differentiate themselves from other professionals and their wish to claim authority and status based on their unique expertise:

Formation of the ASCE [Amcrican Socicty of Civil Engineers] and other engineering organizations signalled the emergence of selfconsciousness in America's engineers. This emergence stood as a part of the more general late-nineteenth century division of American society in which expcrtise replaced the earlier concept of character as the sine qua non for evaluating competence. Engineers began to identify themselves as a group fundamentally different from other people. . . They argued that special knowledge and skill-expertise-characterized each engineering division and made it distinctive, and mastery of that expertise entitled those engineers to special authority. (Marcus and Segal, 1989, pp. 165-166) 


\section{Ideas about Language like those in Middling Rhetoric}

Therefore, when researching the development of ideas about technical language in America, it seems more fruitful to use evidence from publications of engineering societies and from early technical writing textbooks rather than to focus exclusively on the influence of Baconian notions or on "great" exemplars like Franklin or Carver. Language is a social phenomenon; technical language should be understood in social terms. Other motifs considered in social and intellectual history also prove helpful in producing a broad account of the development of professional varieties of American English. For instance, Enlightenment science concentrated on the standardization of terminologysomething the historian of science George Daniels (1971, pp. 96-100) calls a triumph. Thus, ideas concerning the standardization of technical terminology in America can be linked to the history of European science. But again, however, important and more immediate indigenous developments cannot be ignored. Because 'System' was the touchstone of late-nineteenth- and early-twentieth-century America" (Marcus and Segal, 1989, p. 133), because this era was intensely concerned with standardization, systematization, and specialization (Hays, 1957, pp. 4-16), the idea of standardized terminology would have had a powerful resonance in the Sample Textbooks and among engineers in general (Hagge, 1995).

This same idea in part accounts for the highly formal, systematic presentation of material in early technical writing textbooks. The appearance of such a thorough-going formalism takes on additional, albeit paradoxical, interest when one considers that the era in which they were written was characterized by what one American historian has called a "revolt against formalism" (White, 1952; see also May, 1964). Anti-formalism was certainly a motif in progressivist education (Hofstadter, 1963, pp. 323-390, esp. 368387). It is an irony of intellectual history that the academic philologists responsible for promoting the idea of expert-scientific language, which one can connect to the idea of language specialization in the conceptualization of engineering language, were also responsible for promoting linguistic relativism, especially in language education during the Progressive era (Cmiel, 1990, pp. 236-257, esp. 237-242 and 255-257). Such linguistic relativism accounts for a diminution in contemporary composition theory of the importance of formal discourse conventions, leading to, as I have argued elsewhere, an unrealistic conception of disciplinary discourse (Hagge, 1994). Although influenced by expert-scientific rhetoric, the Sample Textbooks 
highly and uniformly value formal discourse conventions and the allied idea of linguistic correctness, as appears below (see also Hagge, 1995).

Use of ideas from Cmiel's category of expert-scientific language in the conceptualization of engineering language parallels a wider development that led a Pulitzer Prize-winning American historian to title a book chapter "The Rise of the Expert" (Hofstadter, 1963, pp. 197-229). During the latter half of the 19th-century, a broad cross-section of the American populace began to think that public problems should be solved by experts who could dispassionately apply to them the rational and factually based scientific method instead of committing the public welfare to rapacious and self-serving politicians (Daniels, 1971, pp. 297-298). Raymond Merritt (1969) has provided evidence that American engineers deliberately cultivated the role of expert as public manager. Because engineers were trained to do problemsolving and to handle complex activities using sophisticated analytical techniques, they soon were relied on to handle not only the technical details but also the overall operations of the organizations that hired them. Their managerial competence, their desire to rationalize American society, and their zeal to reform America morally made them proponents of progressivist ideas:

The engineering profession was primarily responsible for nineteenthcentury American technological growth and . . . many of the leaders of this group realized that they were promoters of both material and cultural change. By emphasizing mobility, efficiency, standardization, improved living conditions, and a less burdensome life, engineers ushered in a cosmopolitan perspective, a new educational curriculum, and a new trend toward scientific management, and modified a whole maze of institutions. They often pictured themselves as the vanguards of civilization who stimulated intellectual thought and promoted the cxpansion of cultural values, as well as developing natural resources and fulfilling matcrial needs. (Mcrritt, 1969, p. 2)

As appliers of scientific knowledge to public and private enterprises, engineers had to interact not only with other experts, but also with "corporation trustees, political leaders, the general public, and common laborers" (Merritt, 1969, pp. 60-61). To communicate with such variegated laypersons, engineers obviously could not use language as defined by expert-scientific rhetoric, with its emphases on a specialized vocabulary and on communication with other specialists. Paradoxically, engineers' very expertise and scientific training, which had made them effective managers, also caused them not to adopt 
wholesale the tenets of expert-scientific rhetoric. This section of my paper establishes affinities between the language variety that the Sample Textbooks suggest engineers should adopt to communicate with lay audiences and what Cmiel has called "Saxon eloquence," an aspect of "middling" rhetoric.

\section{Ideas About Engineering Language and the American "Saxon Eloquence" Movement}

Parallelling the rise of popular democracy in America, there also arose uses of language that deliberately undercut the norms of genteel rhetoric. The "colloquial" type of middling rhetoric was characterized by its deliberate informality and use of slang and regional folk dialects (Cmiel, 1990, pp. 5859). It employed a calculated bluntness that might degenerate into deliberately insulting speech. Moreover, this anti-genteel language used grossly inflated diction: it was noted for bombastic pomposity; bizarre technical jargon used by hucksters and purveyors of patent medicines to inspire awe; and euphemisms motivated by Victorian prudery and designed to rid language of sensuous connotations (pp. 63-66). To many, this highly colloquial language, exemplified in print by popular ("yellow") journalism (pp. 60-64) and mass advertising (pp. 258-259), was an anathema. In reaction to this "low" popular language but also to the perceived linguistic elitism of the 18 th century, the idea of "Saxon eloquence" developed. Its advocates, who had links with Romanticism, wished to create a language that achieved sublimity "by merging the lofty with the rustic" (Cmiel, 1990, p. 95). Especially characteristic of Saxon eloquence was employment of the naturally occurring lexicon and syntax of spoken language rather than use of artificial rhetorical figures; a marked distaste for bombast, slang, and euphemism; and a strong preference for Anglo-Saxon rather than Latinate diction (pp. 94-122). For the sake of subsequent discussion, it is important to note that Saxon eloquence was thought refined in its own way; two of its exemplars were the King James Bible and Shakespeare's plays (pp. 112-115). But it was explicitly adapted to American circumstances, accepting of some provincialisms, plain and practical, and designed to promote democratic ideals and communication with nonspecialists using a common touch.

Ideas about American engineering language doubtless were influenced by the notion of scientific plain style, but a more immediate source of the plainness motif is indigenous Saxon eloquence. The modified colloquialism at the core of Saxon eloquence has strong affinities with an extraordinarily prevalent motif in my sources, the idea that engineering language should be 
simple and economical, natural and conversational. The idea that spoken language-conversation-should be the norm for some types of engineering discourse, especially for the multitudinous letters engineers must write, runs through the Sample Textbooks. "The key-note of good writing, as of good manners, is B natural" (Rickard, 1920, p. 11 [original emphasis]). Naether and Richardson (1930, p. 60) repeat this quotation without attribution, and Rickard (1920, Ch. 2, pp. 11-18) devotes a chapter to "Naturalness." For McDonald (1929, p. 19), "Written sentences should imitate the sound of the human voice." "One of the best ways to avoid a trite style," Howell claims $(1930$, p. 31), "is to write as one would speak." "The writer [of a professional letter] should write exactly as he would talk to his reader if the two were face to face. He should attempt to visualize the reader, to feel the effect of each phrase, and to write simply and naturally" (pp. 196-197). The idea that the conversational norm is a natural one also is explicitly articulated by Baker (1924, pp. 52-53). It is best summarized in this Sample Textbook extract:

As far as is possible to do so in writing, the writer should express himself on the written page as if the addressee were sitting across the desk from him. This style of writing should not, however, lead the engineer to take the short-cuts of oral presentation or of dircct conversation. These would have a tendency to be unintelligible in the written communication. There would not be the inflection of the voice, the gesture, the facial expression which aid oral presentation. Writing as if the addressee were sitting across the desk from the writer implies directness in presentation, naturalness of approach, straightforwardncss of statement, frankness of dealing and the use of the simple word in preference to the complex and ornate. Man-to-man wording will make for courtesy and tact, if rightly interpreted, not for brusqueness and abruptness. (Harbarger, 1923, pp. 54-55. Sec also Gaum and Graves, 1929, pp. 40-41; Watt and McDonald, 1925, pp. 381-387)

As they did in their subtle treatment of specialist language, Sample Textbook authors again display their linguistic sophistication when working with the idea of a spoken-language norm for engineering discourse. In the inset quotation above, Harbarger (1923, pp. 54-55) points out that what today's linguists call paralinguistic cues-for example, gestures-cannot accompany writing as they do conversation. She makes a related point (p. 143): Naturally occurring conversation is elliptical, since it relies on mutual but unstated contextual knowledge that discourse participants share, as discourse 
linguists have remarked (Bach and Harnish, 1979; Brown and Yule, 1983; Smith, 1982). Therefore, Harbarger rightly asserts that writing may not take the shortcuts of conversation, agreeing with Olson (1977) and others who posit far-reaching differences between speech and the much greater linguistic explicitness of written texts. In fact, Naether and Richardson (1930) take this line of reasoning one step further while reinforcing the idea that written language is perforce less "natural" than speech:

It has been said that "the keynote of all effectiveness in speaking and writing is B natural." But this would be true only if art were natural, whereas, while it is perfectly natural for us to create art and to desire it, art is highly artificial; perhaps nothing is more so. Let the engineer remember that his discourse, like his bridges, his aqueducts, his lighthouses, his dynamos, is a product of highly evolved antifice, in the broadest sense of that term, and not a product of nature. What he should aim at in his speaking and writing, and what, when accomplished, is no mean triumph of engineering skill, is discourse free from obtrusive antificiality but pleasing in itsartifice (choice, arrangement, general design). (pp. 60-61 [original emphases])

The idea that the most "natural" sounding discourse has been produced by artifice is a commonplace of classical rhetoric, receiving definitive treatment in Cicero's De oratore. Along the same lines, Barber (1993, p. 215) comments that although Sprat's famous passage on plain language mentions a return to "primitive purity," the "plain" style is actually a "highly sophisticated achievement." Paradoxically, in early technical writing textbooks the idea that engineering language should be "natural" is enunciated via highly formalized conventions. Again, this conventionalized naturalism contrasts strongly with a concurrent anti-formalism in composition theory (Hagge, 1994).

So far, the idea of plain language in the Sample Textbooks still appears to resemble somewhat the idea of the rhetorical plain style as understood by the tradition of the Royal Society-although motivations for its employment differ considerably in the two traditions. But my argument that this idea can be connected to indigenous American developments is strongly supported by two additional, linked pieces of evidence. First, Sample Textbook authors insist that plain-style engineering language should at all costs sound refined. Second and concomitantly, these authors attack low, vulgar language and pompous, inflated, "fine writing" - the same sort of language use that for Cmiel characterizes the "colloquial" strain of middling rhetoric. The con- 
stant linkage of plain-style ideas with criticisms of the hyperbolic language of popular journalism (for Cmiel [1990, pp. 134-36] typical of colloquial middling rhetoric), advertising, and the like in the Sample Textbooks thus corroborates their connection with the indigenous American Saxon-eloquence movement, which took pains to encourage a modicum of linguistic refinement. For instance, in insisting that when writing business letters engineers should use a conversational style, Harbarger (1923, p. 143) warns that although the use of such a style "will tend to keep the tone of the letter from being too formal and too remote, it must maintain dignity. It must not take the legitimate shortcuts of direct man-to-man talk." The Sample Textbooks thus advocate a mean between the extremes of uncontrolled, sloppy language and overly refined, pretentious language:

[S]tyle [in language] may be compared to the clothes one wears; language and clothes influence associates in much the same way. A person who uses slovenly language is like a person who wears unkempt clothes; a person who affects pompous language is like one who wears pretentious and ostentatious clothes; a person who has a small vocabulary at his command and who cannot handle language with grace and facility is like a person who has only one suit of clothes and feels uneasy in other garments. The course that corresponds to dressing modestly but well is to use simple, clear language. (McDonald, 1929, p. 93)

In addition, McDonald contrasts simple but forceful King James Bible language, an exemplar of the idea of Saxon eloquence, with overblown academic writing (p. 92). Other affinities with ideas from the Saxon-eloquence movement occur in the Sample Textbooks, which contain evidence that engineering language should not include rhetorical flourishes such as those in 18th-century rhetoric, against which proponents of Saxon eloquence were reacting. The motif of avoidance of antiquated, unnatural letter-writing jargon appears, for instance, in Watt and McDonald (1925, p. 387) and Gaum and Graves (1929, p. 40). "Fine writing" gets roundly condemned in the textbooks, in ways that unmistakably point to the influence of the Saxon-eloquence movement. Frost (1911, pp. 49-50) condemns the excesses of popular journalistic prose just as Cmiel shows the supporters of Saxon eloquence did: "Fine writing' is a fault-it is used in newspapers, sometimes for the sake of elaborating on details, or, in other words, to fill space." Others too support this attack on the fine writing, verbosity, and overly rhetorical language that 
characterize colloquial rhetoric:

A worse fault than careless jargon is the "fine writing" which many American editors seem to favor. ... If America has carried to extreme an uncouth indifference to good English, and a frontier carelessness of style, it has also nourished side-by-side with it a too-precious ornateness of scholarship, a pompous floridness that reminds one of muchdecorated Central American generals or high potentates of Siam. The belief of those who flaunt this high-flown manner seems to be that short straight speech is not good enough for them, and they invent verbal gecgaws and pinwheels to embellish their sentences. ... Such writing is reminiscent of the eighteenth-century poets whocalled a grave an "earthly couch" and a bird a "winged denizen of the air." (Watt and McDonald, 1925, p. 161. See also Frost, 1911, p. 50; Gaum and Graves, 1929, p. 46; Howell, 1930, p. 106; Naether and Richardson, 1930, p. 60; Rickard, 1920, pp. 14-15)

This quotation attacks in combination several aspects of colloquial middling rhetoric-its conjunction with American newspaper style, its links with the American frontier (Cmiel, 1990, pp. 55ff.), its crass flaunting of verbal exuberance. Another textbook author, who makes numerous literary allusions and certainly is not anti-literary in outlook, also cautions against overuse of rhetorical figures: "The use of a simile where none is needed merely suggests "fine writing"' (Solberg, 1929, p. 101). Howell (1930, p. 71) advises "the engineer" to "choose the shorter and less ornate" expression "where it is possible to say a thing in more than one way." Specifically, rhetorical flourishes for their own sake are discouraged because they draw attention to themselves rather than to the information being conveyed by the discourse. In terms of Jakobson's (1960) six-part division of language function, the Sample Textbooks implicitly claim that the primary functions of technical discourse are referential and conative, focussing respectively on subject-matter and addressee. Poetic language, the function of which is to focus attention on language in and of itself, is little used. But the textbook stand on use of rhetorical figures is nuanced. A pragmatic reason, reader interest, may override the dictum about avoiding them, as Baker (1924, p. 60) advises: "A writer ... is under no obligation to be dull, to be monotonous, to be pedestrian. There are few rhetorical devices which cannot be employed to advantage."

Abraham Lincoln, for Cmiel (1990, pp. 116-120) a user par excellence of language in the Saxon eloquence tradition, is mentioned several times in 
my sources. McDonald (1929, pp. 76-78) calls him "one of the most convincing and impressive of American letter-writers," citing him as an example of forceful writing because he "utilized short sentences and common words in a way that commanded respect," and quoting several extracts from his correspondence. Harbarger (1923, p. 249) also mentions Lincoln's letters favorably. Watt and McDonald (1925, pp. 407-408) praise him for his "simple direct naturalness." These mentions of Lincoln forge another link between the Sample Textbooks and ideas about language in the Saxon-eloquence movement. But the fact that he is judged "almost too colloquial" by one pair of writers (Watt and McDonald, 1925, p. 407) indicates that engineering language, while imitating speech, still was conceptualized in the Sample Textbooks as ultimately being refined.

Use of simple, common language-again, a hallmark of Saxon eloquence-also characterizes the Sample Textbooks' concept of engineering language. Diction should be simple and characterized by common words (Frost, 1911, p. 49; Harbarger, 1923, p. 107; Howell, 1930, p. 191; Naether and Richardson, 1930, p. 26). Engineering language is implicitly conceived as a mean among overly rhetorical, pedantic language use; low, disreputable language; and language so brusque that it offends. "A professional man, an engineer in particular, should express himself precisely and moderately. He should avoid, on the one hand, a pedantic style, and, on the other, a slipshod and uncouth style. . . But at the same time the engineer should not cultivate too curt and business-like a style." (Watt and McDonald, 1925, pp. 150-151). As did proponents of Saxon eloquence, textbook authors inveigh against overwrought language - against, it would appear, the colloquial strain of middling rhetoric. Both Watt and McDonald (1925, p. 150) and Rickard (1920, p. 134) quote the influential British stylist Quiller-Couch on this matter; the latter connects the use of jargon, a term Quiller-Couch popularized, to fine writing in general (Rickard, 1920, pp. 134ff.). But a paradox occurs because, as already has been discussed, engineering language is supposed to use technical terms of trade, sometimes characterized asjargon and certainly not characteristic of simple, common language. Again the notion of the dual role of the engineer as specialist and manager resolves the paradox: Technical language is used only for an audience of adepts, more common language for non-experts. Gaum and Graves (1929, p. 61) assert that "Writers have learned to translate technical facts into common language, rather than to hold to their specialized vocabularies" (original emphasis). An engineer's need to interact with many different types of people, as established by Merritt (1969, esp. pp. 
$27,57-62,101-107,138,159-161)$, appears to be connected in the Sample Textbooks to ideas about specialized versus everyday diction:

The Choice of Technical Words. In the choice of words the chief object of the engineer should be to make himself clearly understood, not in New York or San Francisco alone, but by the capitalist, manufacturer, contractor, or their engineering representatives, in any city of the land, and possibly in other countries as well. If, then, the engineer can find a word ready at his hand which is in common use and of unmistakable meaning, he will generally do better to adopt it than to try to introduce some other word which may be more correct from the etymological viewpoint. (Frost, 1911, p. 40)

Thus, much evidence demonstrates that ideas about engineering language as codified in early 20th-century American technical writing textbooks emphatically were not influenced solely by the Baconian tradition of scientific language. References in the Sample Textbooks to the excesses of contemporary newspaper language, to the hyperbolic language of American advertising, and to American exemplars of common language such as Lincoln, for instance, demonstrate a seemingly indisputable connection to the indigenous American idea of Saxon eloquence. Conversely, although the Sample Textbooks do indeed advocate use of technical language as did the proponents of expert-scientific rhetoric, this language register is limited to the context of specialist interaction; it is not given an absolute value as Cmiel has shown was the case in expert-scientific rhetoric. A final paradox concerns the AngloSaxon vocabulary preferred by proponents of Saxon eloquence (Cmiel, 1990, pp. 94-95). A similar preference appears strong in some textbook authors (e.g., Howell, 1930, pp. 21, 25, 191), and Anglo-Saxon purism also develops in early 20th-century business communication and English composition textbooks (Hagge, 1989). Influential 19th- and early 20 th-century style guides, both British and American, including Spencer's "The Philosophy of Style," work by the Fowlers, and somewhat later, by Strunk, Orwell, and Flesch, also treat this issue. Nevertheless, Rickard (1920, pp. 6-7) and Naether and Richardson (1930, p. 38) betray an independence characteristic of Sample Textbook authors and a knowledge of historical linguistics in arguing against slavish Anglo-Saxon purism. This formulation is typical:

In technical writing it will be found that words of Latin origin help to make nice distinctions of meaning and establish the precision for which 
we strive constantly. The short and simple Anglo-Saxon may suit the poet's purpose, but the engineer will discover that many old-fashioned English words have associations and meanings unfitting them for his special use. This applies to numerous preposition-verbs, which, idiomatic though they be, and an essential part of our language, should be avoided or used sparingly by the technical writer. They came into every-day use long before modern science was developed and they carry with them the looseness of meaning characteristic of colloquial speech. (Rickard, 1920, p. 95)

A last blending of ideas taken from the Baconian tradition with indigenous American motifs occurs when Sample Textbook authors treat "linguistic economy." The notion that scientific discourse should be concise is certainly part of the Baconian plain-style tradition (Barber, 1976, p. 134). But in the late 19 th and early 20 th centuries, this idea derives additional persuasive force from Herbert Spencer's (1878) extraordinarily influential essay "The Philosophy of Style":

On seeking for some clue to the law underlying these current maxims, we may see shadowed forth in many of them, the importance of economizing the reader's attention.... A reader or listener has at each moment but a limited amount of mental power available...hence, the more time and attention it takes to receive and understand each sentence, the less time and attention can be given to the contained idea; and the less vividly will that idea be conceived. (p. 11)

The idea of economizing reader attention is extremely popular in the Sample Textbooks. Spencer gets explicit credit for it at least twice (Rickard, 1920, pp. 9-10; Watt and McDonald, 1925, p. 157), but it is referred to without authorial attribution in numerous other textbooks (Earle, 1911, pp. 16, 30, 32; Frost, 1911, p. 64; Harbarger, 1923, pp. 59, 211; McDonald, 1929, p. 91; Naether and Richardson, 1930, p. 52). That the ideas of Spencer, particularly those concerning social relationships, to which Spencer lent the cachet of science, were hugely influential in America is a commonplace in intellectual history (e.g., Curti, 1964, pp. 552-554; Daniels, 1971, pp. 248-253, 262264). But one might also link the idea of linguistic economy with the American idea of efficiency as a gospel (Curti, 1964, pp. 680-82; Lerner, 1957, pp. 230ff.), of which many engineers were vociferous missionaries (Marcus and Segal, 1989; Merritt, 1969; Ostrander, 1970, esp. pp. 197-273). And of course 
the notion that one should not use more words than necessary also was part of the indigenous American Saxon-eloquence movement (Cmiel, 1990, p. 111). Thus, the way in which the idea of linguistic economy is deployed once again demonstrates that the conceptualization of engineering language in the Sample Textbooks complexly conflates various strands in American thought about language, especially ideas about language that, as Cmiel has demonstrated, were competing for public acceptance during the period under consideration.

\section{Ideas about Language like those in Genteel Rhetoric}

"In striving for a dignified, thoughtful style suggestive of an educated man not entirely preoccupied with dollar-chasing," Watt and McDonald (1925, p. 155) suggest, "the professional man by all means should avoid the pompous manner of the many verbose writers who evidently have never heard of that sterling rule, "eliminate the superfluous words." Here conciseness, a motif that blends the Baconian tradition with American ideas about Saxon eloquence, is linked with another prevalent idea in the Sample Textbooks, the dignity of engineering language. As Cmiel (1990, p. 116) points out, Saxon eloquence often slid back up the social scale to approximate genteel language. In this section I will provide evidence that engineers felt compelled to assert and maintain their social status and that they wished to use a dignified language commensurate with that status. Reflecting as usual the concerns of the engineering profession, the Sample Textbooks therefore combine ideas about language drawn from the expert-scientific and Saxon-eloquence traditions with those from the older tradition of genteel rhetoric. According to Cmiel (1990, p. 127), this last tradition clearly was concerned with the way in which language use maintains a social hierarchy. Refined speech, "one indication of character" (p. 28), "had to be watched, controlled, so that it did not turn harsh or vulgar" (p.31). "Late nineteenth-centurydefenders of civility were not simply consumed by the trivia of manners or unable to come to terms with the emerging industrial order, as their critics so often charge. They were, rather, defending a certain way of life that had long had serious ethical status" (p. 203). Engineers too were concerned about status, cast themselves as social and civic benefactors, and stressed constant, consummate professionalism:

Members of the [engineering] profession...were concerned about their own status and security. They consistently compared themselves to 
lawyers, doctors, and ministers and marked their own advancement in terms of the standards of learning, service, and prestige which these three older callings had enjoyed.... [An engineer's] status depended upon his personal ethical standards, his learning, and his professional accomplishments. In this respect the engineer had to rely upon his claim as a learned professional more than did the established practitioners of law and medicine. (Merritt, 1969, p. 9. See also Haber, 1991, p. 311)

\section{The Dignity of Engineering Language and the Status of the Engineer}

Because of their highly visible position in society and because of their desire to maintain a level of status comparable to that of the medical, legal, and ecclesiastical professions, engineers manifested an extraordinary sensitivity toward language use and took great pains to ensure that their professional dignity would be properly reflected in their linguistic choices. The Sample Textbooks reflect this concern with dignified language:

Everything considered, the engineer has reason to be particularly careful in his employment of language. As an intellectual leader, and a man of judgment and taste, he has high traditions to maintain. His choice of words and literary style are often taken as criterion [sic] of his professional skill and character. (Watt and McDonald, 1925, p. 156)

The many Sample Textbook references to the idea of a dignified language appropriate to the engineering profession reflect over and over again this sociolinguistic consciousness. For Watt and McDonald (1925, p. 381), "Courtesy in a business letter does not mean undue familiarity... A uniform tone of dignity and self-respect in business letters is much to be preferred to a blatant and vulgar over-desire to please." They also compare the engineer to other professionals-physicians, teachers-and exhort engineering letterwriters "to indicate a dignified 'professional' bearing and a temperament influenced as much by a desire to add to the world's knowledge as by the pursuit of gain" (pp. 152-153). Gaum and Graves (1929, p. 2) comment that "report-writing today is taking on a new dignity" and that the one-sentence paragraphs routinely found in sales letters are not "sufficiently dignified" for a long engineering report (p. 101). McDonald (1929, p. 72) counsels that writers of informal reports should aim at "a conversational but dignified tone." Harbarger (1923) recommends a conversational style for engineers' business letters; such a register "will tend to keep the tone of the letter from being too 
formal and too remote," but still "it must maintain dignity" (p. 120). Likewise, a request for a letter of reference from a former engineering professor "should observe the amenities and the personal yet dignified tone" (p. 120).

Several textbook authors use a clothing metaphor to reinforce this point. Watt and McDonald (1925) condemn "the general slovenliness of diction and rhetoric," "the slapdash and 'live-wire' argot of the street and market" that many businessmen use. "Such jargon seems to them to have more punch than a sober and restrained style, just as many of these writers wear clothes that figuratively punch you in the eye, instead of the modest clothes of the professional man" (Watt and McDonald, 1925, p. 161; see also McDonald, 1929, pp. 3-4, 93; Rickard, 1920, p. 64). Along the same lines, professional standards are connected to the observance of the conventions of English usage (e.g., Earle, 1911, pp. 219-220; Gaum and Graves, 1929, p. 36; Howell, 1930, p. 137). For Frost (1911, p. 5), "The professional engineer is naturally looked upon as an educated man" who therefore should be "conversant with the elements of grammar, spelling, and punctuation." Harbarger (1923, p. 17) opines that "errors in the technique of expression have a tendency to discredit the person or the company that permits written material to go out that is not letter perfect, or that sends out representatives who seem by their speech to be illiterate." McDonald (1929, pp. 3-4) reverts to the clothing metaphor: "A man may wear unfashionable or freak clothes and pose as 'a rough diamond,' but uncouth and ungrammatical language used in letters and reports invariably produces a bad impression." So also Harbarger (1923, p. 21): "A man's language, . . is taken by most to indicate not only his literacy but also his background, the grade of society in which he has placed himself, his tastes, his aspirations, his diligence, and his appreciation."

Just as today's sociolinguists do, then, the Sample Textbook authors connect language use with social class, profession, and level of education. Since language conveys such distinctions, engineers must use language indicative of their manifestly high level of culture and education. The notion that language reflects character is, as has been mentioned previously, the leading idea of genteel rhetoric (Cmiel, 1990). Although the account of engineering language in the Sample Textbooks contains conceptualizations about language from the expert-scientific and Saxon-eloquence rhetorics, the evidence presented in this section demonstrates that at its core remain ideas from the genteel-rhetoric tradition. Again, paradoxes occur because of this amalgamation of different ideas about language. For instance, although authors of the Sample Textbooks, influenced by the Saxon-eloquence 
tradition, exhort their readers to use common, everyday language, they also advise that the general tenor of engineering language should remain formal. For Naether and Richardson (1930, p. 4), "a certain formality or conventionality is characteristic of thought discourse"; thus, linguistic "eccentricities of all sorts are avoided, and even minor idiosyncrasies as well. These things are held likely to detract from dignity, as indeed they may; and presentation of serious thought often has need for all the dignity it can command." Although a colloquial register is posited by Saxon eloquence, this idea is mitigated in engineering language because colloquialisms and a concomitant exaggerated informality were suspect, just as they were in the genteel rhetorical tradition (Cmiel, 1990, pp. 128--29). Harbarger (1923, p. 54) cautions that "The tone of the business communication should be personal and individual, but not familiar." Rickard (1920, p. 99-100) asserts that "preposition-verbs [nowadays called phrasal verbs by linguists] are idiomatic.... They should be used sparingly in technology, which cannot suffer careless colloquialisms without serious loss of clarity." Howell (1930, p. 25) argues similarly: "Colloquialisms, that is, loose expressions tolerated in ordinary conversation, are not considered good usage in formal writing."

The Saxon-eloquence movement did support the use of folk-based idioms, but neither it nor engineering language descended to the low register characteristic of the uneducated or of, say, the deliberately vulgar purveyor of patent remedies. On the contrary, Sample Textbook authors stress that engineers must convey their educated background through careful language use (Rickard, 1920, p. 14):

The writer is describing a method of mining and uses the language of an uncducatcd laborcr, perhaps with the idca that it sounds "practical."

The language is "natural" to a semi-literate promoter but not to an educated engineer. Do not mistake vulgarity for case, nor inaccuracy for freedom....

This also illustrates an uncouthness that simulates naturalness. The writer, a graduate of a university, has fallen into the style of those about him in the mining community.

Although the academic philologists who promoted expert-scientific rhetoric quite deliberately recommended incorporation of slang, folk idioms, 
and regional dialect features into the standard language, and although the colloquial strain of middling rhetoric certainly employed relatively uncultivated forms of language, engineering language harks back to the genteel rhetorical tradition in vehemently eschewing such forms. Especially to be avoided is the unduly familiar language of colloquial middling rhetoric found in popular journalism and advertising argot, as the quotation from Rickard directly above indicates. Watt and McDonald (1925, p. 158) claim that "The bumptious and too-slangy sporting pages of the 'yellow journals' are likely to debase the literary style of the reader," and they condemn slovenly business jargon, as noted earlier, "the slapdash and 'live-wire' argot of the street and market" (p. 161), as does Howell (1930, p. 2). (The latter does admit that language must be adapted to readers and that "a letter written to college men might contain college slang and other expressions that would add freshness and point to the letter" [pp. 191-192]). McDonald (1929, p. 141) asserts that "any noticeable addition to the journalese of our daily papers should be avoided," along with "legal jargon." As it is in the tradition of genteel rhetoric, slang is expressly prohibited in several Sample Textbooks. For Earle (1911, pp. 208-209), "current slang is particularly objectionable" because it adds an unsuitably flippant tone to engineering discourse and is inexact; "in every way slang is unfit for use in technical writing." "Slovenly or slangy expressions that become ten times more objectionable after constant use" are roundly criticized by McDonald (1929, p. 18). Even the linguistically sophisticated Naether and Richardson (1930, p. 275), who admit that "slang has its merits," hasten to add that "the man of common sense will make his selection from slang as he makes his selection from the latest popular music; he will reject much and accept little, and that little he will use but little." Rickard (1920), who was trained as a mining engineer and who worked as an engineering editor, particularly scorns engineering slang throughout his book, which addresses practicing engineers as well as students.

Employment of colloquial language, moreover, may encourage incorrect usage (Howell, 1930, pp. 26-28, 169, 172). Although the promoters of expert-scientific rhetoric were thorough-going relativists concerning usage, engineering language coincides not with it but with the tradition of genteel rhetoric in its pronounced adherence to usage standards. Employing conventionally correct linguistic forms helps engineering writers project the image of educated, cultivated professionals who represent their calling well (Earle, 1911, p. 219; Gaum and Graves, 1929, p. 36; Howell, 1930, p. 137). Frost (1911, p. 5) notes that "The professional engineer is naturally looked 
upon as an educated man. He is expected to be a man of good address, and conversant with the elements of grammar, spelling, and punctuation, but not necessarily omniscient, or a master of the whole circle of the arts and sciences." “There is one further reason for the engineer's considering as important the ability to express himself correctly; it is that incorrect expression marks him at once as crude and uncultivated" (Watt and McDonald, 1925, p. 6). Even something trivial like correct hyphen use marks the engineering writer as cultured: "Among scientific men the better educated seem to favor the hyphen more than do the relatively uncultured" (p. 97). McDonald (1929, pp. 3-4) compares engineers who use "uncouth and ungrammatical language . . in letters and reports," as we have seen earlier, to the "rough diamond" who wears "unfashionable and freak clothes." In addition, he and others link linguistic correctness to professional concerns:

The technical man should be especially careful in his use of punctuation. A misplaced comma in a set of specifications or in an order for apparatus may cause such havoc as a bad accident or a serious financial loss, whereas a misplaced comma in a poem or a play or a novel rarely has any worse effect than a momentary obscurity in the entertainment of the reader. The technical man should use language and punctuation as accurately and carcfully as he uses formulas and the apparatus of his craft. (McDonald, 1929, pp. 124-125. Scc also Howcll, 1930, pp. 3, 9)

Thus, the idea that engineers as specialists must use characteristic expertscientific language is conflated with the idea from genteel rhetoric that language is an outward expression of inner character. A practical concern of the expert, avoidance of legal entanglements (Howell, 1930, p. 115; McDonald, 1929, p. 125; Solberg, 1929, p. 43; Watt and McDonald, 1925, p. 88 ), is linked with employment of correct usage conventions. In turn, observance of linguistic correctness marks the expert engineer as cultured and the engineering profession as a dignified one worthy of the same respect as other, more established professions. Likewise, some textbook authors explicitly create an analogy between other aspects of professional practicefor instance, the use of mathematical formulae - and linguistic correctness. Once more, engineering language is viewed as avoiding linguistic extremes, as representing a mean between the uncouthness of colloquial rhetoric, the acceptance of "low" forms on the part of expert-scientific rhetoric, and the stilted preciosities into which 18 th-century rhetoric could lapse: 
[I]f the average American makes a special attempt to avoid uncouth English, he is likely to commit as bad mistakes in the other direction by employing over-elegant, stilted, and ridiculous expressions that show lack of facility with the language and of a sense of proportion.... The reaction from schoolmarmism is slovenly and slangy colloquialism.... The teaching of English should emphasize how to attain a practical command of the language without going to the extremes of schoolmarmism or of colloquialism. (McDonald, 1929, pp. 83, 87)

The material quoted so far demonstrates some strong affinities of engineering language as described in the Sample Textbooks with genteel rhetoric. The reason for this connection appears in the final motif that I will discuss, in which the engineer is presented as a person of true character-as a cultured gentleman. Like the genteel citizen rhetor, the engineer is a person of affairs who has the general interests of humanity in mind (Frost, 1911, pp. 1-2). Like the genteel rhetor, the engineer must realize that his use of language and his character are linked (Harbarger, 1923, pp. 21, 25; Rickard, 1920 , p. 64). This language must reflect the status of the engineer in society. It must be the language of a gentleman (Harbarger, 1923, p. 182-184, 234; Howell, 1930, p. 195), a gentleman with broad cultural interests. Several of the Sample Textbooks mention canonical literary or other artistic works or provide lists of such works so that the engineering student and professional engineer may do what is called "cultural reading" (Aydelotte, 1917; Harbarger, 1923; McDonald, 1929; see also Park, 1926; Hagge, 1995). The cultured engineer is educated and literate (Harbarger, 1923, p. 179; Watt and McDonald, 1925, pp. 50-51) and can empathize with and serve others (Harbarger, 1923, p. 179) with honor (Baker, 1924, pp. 70-72). Aydelotte (1917) reinforces the ideas of the cultured engineer and cultural reading by including in his anthology the essays of several practicing engineers who advocate such ideas. One of these engineers, the pre-eminent John Lyle Harrington, perhaps best summarizes the attitude of the entire profession toward engineering language. (That this material first appears in an address given before any of the Sample Textbooks were published corroborates my contention that the Sample Textbooks do indeed reflect contemporaneous engineering practice).

The character of the technical man's language is important in his social and business intercourse; in his business and professional correspondence; in the promulgation of orders, rules, and regulations for the guidance of those under his direction; in the preparation of 
specifications, contracts, and reports; in writing and delivering addresses and technical papers; and in writing technical books for the advancement of his profession....

A technical man is, presumably, an educated man; and if he do [sic] not speak like one, suspicion is cast upon the entire range of his learning. When a man cannot spell correctly, or use ordinarily good grammar...it is difficult to convince others that he is professionally able.... One who is...ignorant of the language finds social progress substantially impossible....

Language has large weight in classifying a man, infinitely more than manner or dress....

There are many vocations in which it is not essential that a man be cultured and intelligent; but the technical professions are not among them....

The detrimental results of bad English...arc by no means so certain as in the more formal technical papers... The idea that a technical paper is dry at best, and that the English cmployed in it is of small consequence has long becn proved incorrect. (Quoted in Aydelotte, 1917, pp. 52-56; original in Waddell and Harrington, 1912, pp. 60-63)

\section{Conclusions and Suggestions for Further Study}

The development of ideas about engineering language in early 20thcentury technical writing textbooks might be seen as an attempt to answer the deliberately paradoxical questions McDonald (1929, p. 153) poses at the beginning of his chapter "Cultural Reading for the Technical Student," which culminate with "How can culture be linked with a machine age?" Just such a linkage is accomplished in the Sample Textbooks, I have argued, by rather paradoxically conflating ideas prevalent in 19th- and early-20th-century America about three types of language. This conflation makes sense when examined in light of a number of trends delineated by American social and intellectual historians. Because engineers saw themselves as civic leaders, and because they wished to maintain their status as part of a cultured, professional elite, they adhered to some of the norms of genteel rhetoric, which emphasized the use of a dignified and linguistically correct register of En- 
glish. Such usage reflected their character and their professional standing as on a par with doctors, lawyers, and ministers (Marcus and Segal, 1989; Haber, 1991). The Sample Textbooks' emphasis on dignified, correct English, and their concern with the status of the profession, mirrors a similar emphasis in addresses of eminent practicing engineers and engineering professors as definitively collected in Waddell and Harrington (1912), in influential national reports concerning the profession (Mann, 1918; Wickenden, 1930), and in articles in Engineering English, the professional journal of the Society for Promoting Engineering Education (Hagge, 1995).

But because engineers saw themselves as experts, even as scientists, and because they needed to communicate with other specialists, they ignored the stigma in genteel rhetoric against technocratic talk, freely employing terms of trade as in expert-scientific rhetoric (Cmiel, 1990), the development of which is connected with the rise of industrialism and the progressivist cult of expertise in late 19th- and early-20th-century America (Hays, 1957; Hofstadter, 1963; May, 1964). And because their interactions were not just confined to other specialists (Merritt, 1969), because their role of expert manager made it imperative that their communication have the "common touch," because they wished to avoid the stigma attached to degenerate "fine writing," they adopted some ideas from the Saxon-eloquence movement without, however, condoning the excesses of the allied colloquial strain of middling rhetoric. Again, sources other than the Sample Textbooks seem to corroborate the fact that the engineering profession as a whole shared these ideas about language use. I have argued that early-20th-century technical writing textbooks explicitly conceptualize engineering discourse as a specialized variety of American English characterized by its unique linguistic behaviors. Perhaps most important is the ability to shift register to adapt to differing fields, or subject matters, and differing tenors, or degrees of formality - while at the same time never deviating from the architectonic idea of dignified, relatively formal language use that conveys the professional character engineers took pains to cultivate.

In closing, I stress that my arguments and evidence certainly are open to change, could be more subtly nuanced, and need more support from primary and secondary sources. A first step in this direction might be to extend my analysis to other early technical writing textbooks, especially those published from 1930-1941 (e.g., Agg and Foster, 1935; Richardson, Becklund, Guthrie and Haga, 1934), that are not later editions of works already used in this study. Articles on writing in early engineeringperiodicals deserve attention 
as well. I have outlined some preliminary results along these lines elsewhere (Hagge, 1995), but much work remains to be done. Second, developments in early technical writing need to be compared with concurrent trends. For example, a number of sources in my study quote popular works on writing and language by authors such as Quiller-Couch, Landor, the Fowlers, and Robert Louis Stevenson. Tracing the influence especially of Stevenson on engineering language might prove interesting, since many of his relatives were engineers. More important, studies comparing ideas about language in early-20th-century composition, business communication, and technical writing textbooks need to be done. Third, the interplay between the formalist conception of language that seems inherent in professional communication and the anti-formalist strain in composition theory initiated by those whom Cmiel has called academic philologists needs to be explicated more fully.

Finally, I reiterate that although I have sketched a history of $i d e a s$ about engineering language here, these ideas are not just abstractions dreamed up by ivory-tower academicians that have no connection to real-world engineering practice or to the practice of technical writing. Instead, ideas about engineering language in the Sample Textbooks are inextricably linked with contemporaneous engineering practice. Again and for the last time, as I have begun to demonstrate elsewhere (Hagge, 1995), Sample Textbook authors worked exceedingly hard to incorporate the realities of current technical communication into their accounts of the conventions of engineering language. The Sample Textbooks contain multitudinous references to actual communicative practice, in, among others, the form of quotations from actual technical documents, reproductions of engineering graphics used in actual texts, and verbatim reprintings of entire real engineering documents, ranging from letters to full reports. In addition, they constantly validate their accounts of engineering language by citing evidence from authoritative professional sources such as engineering journals, the style guides produced by professional engineering associations, and the most reputable textbooks in various engineering subdisciplines. Moreover, what they say about engineering language mirrors ideas about such language presented in the addresses of the foremost American engineers of the time, such as John Lyle Harrington. Anyone who doubts that the engineering profession as a whole did espouse many of the ideas I have traced here should read Harrington's oft-quoted address “The Value of English to the Technical Man" in its entirety, for it summarizes many of the motifs that also occur in the Sample Textbooks. I am, of course, perfectly willing to admit that not all 
early-20th-century technical documents incorporate the linguistic conventions the Sample Textbooks delineate. Technical prose has a long history that stretches back to Old English, and much of it stems from a natural tendency of everyday language toward simplicity of diction and naturalness of syntax (Hagge, 1990). But technical communication is at present a specific discipline, and its disciplinary practices and conventions have been institutionalized by its own professional associations, courses, textbooks, and the like. What the institution of technical communication has become today largely depends on the way in which it first was conceptualized in early-20th-century engineering writing textbooks.

\section{References}

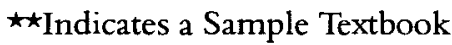

Adolph, R. (1968). The rise of the modern prose style. Cambridge, MA: MIT Press.

Agg, T.R., and Foster, W.L. (1935). The preparation of engineering reports. New York: McGraw-Hill.

Allbutt, T.C. (1923). Notes on the composition of scientific papers. London: Macmillan.

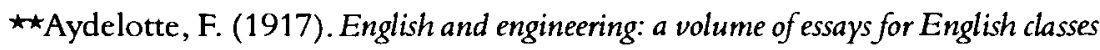
in engineering schools. New York: McGraw-Hill.

Bach, K., and Harnish, R.M. (1979). Linguistic communication and speech acts. Cambridge, MA: MIT Press.

$\star \star$ Baker, R.P. (1924). The preparation of reports: Engineering, scientific, administrative. New York: The Ronald Press.

Barber, C. (1976). Early modern English. London: André Deutsch.

Barber, C. (1993). The English language: A historical introduction. Cambridge, England: Cambridge University Press.

Baresich, M.J. (1980). "The relativity of communication: Albert Einstein as technical writer." Journal of Technical Writing and Communication, 10, 125132.

Batschelet, M.W. (1988). "Plain style and scientific style: The influence of the Puritan plain style sermon on early American science writers." Journal of Technical Writing and Communication, 18, 287-296. 
Bates, R.S. (1965). Scientific societies in the United States. (3rd ed.). Cambridge, MA: MIT Press.

Boas, G. (1969). The history of ideas: An introduction. New York: Scribner's.

Breithaupt, J. (1991). "U.S. Grant, writing to meet the emergency." Technical Communication, 38, 150-51.

Broadhead, G.J. (1985). "Style in technical and scientific writing." In M. G. Moran and D. Journet (Eds.), Research in Technical Communication: $A$ Bibliographic Sourcebook., (pp. 217-252). Westport, CT: Greenwood Press.

Brockmann, R.J. (1983). "Bibliography of articles on the history of technical writing." Journal of Technical Writing and Communication, 13, 155-165.

Brogan, J.A. (1965). “A lesson from Benjamin Franklin, American's first great technical writer." IEEE Transactions on Engineering Writing, EWS 8(1), 3-6.

Brown, G., and Yule, G. (1983). Discourse analysis. Cambridge, England: Cambridge University Press.

Cmiel, Kenneth. (1990). Democratic eloquence: The fight over popular speech in nineteenth-century America. New York: William Morrow. Rpt. University of California Press.

Connors, R.J. (1982). “The rise of technical writing instruction in America." Journal of Technical Writing and Communication, 12, 329-352.

Crystal, D. (1991). A dictionary of linguistics and phonetics. (3rd ed.). Oxford: Blackwell.

Curti, M. (1964). The growth of American thought. (3rd ed.). New York: Harper and Row.

Daniels, G.H. (1971). Science in American society: A social history. New York: Knopf.

$\star \star$ Earle, S.C. (1911). The theory and practice of technical writing. New York: Macmillan.

Fisch, H. (1952). "The Puritans and the reform of prose style". $E L H, 19$, 229-248. 
$\star \star$ Frost, H. (1911). Good engineering literature: What to read and how to write with suggestive information on allied topics. Chicago: Published by the Author. Distributed by Chicago Book Company.

$\star^{\star}$ Gaum, C.G., and Graves, H. F. (1929). Report writing. New York: PrenticeHall.

Gerson, S. (1988). "Commentary: Humanism in technical/business communication." Joumal of Technical Writing and Communication, 18, 345353.

Görlach, M. (1991). Introduction to early modern English. Cambridge, England: Cambridge University Press.

Gramley, S., and Pätzold, K.-M. (1992). A survey of modern English. London and New York: Routledge.

Greene, J.C. (1957/58). “Objectives and methods in intellectual history."Mississippi Valley Historical Review, 44, 58-74.

Grego, R.C. (1987). "Science, late nineteenth-century rhetoric, and the beginnings of technical writing instruction in America." Joumal of Technical Writing and Communication, 17, 63-78.

Gresham, S.L. (1977a). "Benjamin Franklin's contributions to the development of technical communication."Journal of Technical Writing and Communication, 7, 5-13.

Gresham, S.L. (1977b). "Harvesting the past: The legacy of scientific and technical writing in America." In Proceedings of the 24th International Technical Communication Conference (pp. 306-08). Washington, DC: Society for Technical Communication.

Gresham, S.L. (1979). "George Washington Carver and the art of technical communication." Journal of Technical Writing and Communication, 9, 217225.

Haber, S. (1991). The quest for authority and honor in the American professions, 1750 1900. Chicago: University of Chicago Press.

Hagge, J. (1989). “The spurious paternity of business communication principles." Journal of Business Communication, 26(1), 33-55. 
Hagge, J. (1990). "The first technical writer in English: A challenge to the hegemony of Chaucer." Joumal of Technical Writing and Communication, 20, 269-289.

Hagge, J. (1994). "The value of formal conventions in disciplinary writing: An axiological analysis of professional style manuals." Journal of Business and Technical Communication, 8, 408-461.

Hagge, J. (1995). "Early engineering writing textbooks and the anthropological complexity of disciplinary discourse." Written Communication, forthcoming.

$\star \star$ Harbarger, S.A. (1923). English for engineers. New York: McGraw-Hill.

Hargis, C.C., Jr. (1962). "America's first great technical writer." STWP Review, 9 (Jan), 12-13.

Harris, E. (1982). "In defense of the liberal-arts approach to technical writing." College English, 44, 628-636.

Hays, S.P. (1957). The response to industrialism 1885-1914. Chicago: University of Chicago Press.

Hofstadter, R. (1963). Anti-intellectualism in American life. New York: Knopf. Rpt. Vintage Books, Random House.

$\star \star H o w e l l, ~ A . C . ~(1930) . A$ handbook of English in engineering usage. New York: John Wiley and Sons.

Hudson, R.A. (1980). Sociolinguistics. Cambridge, England: Cambridge University Press.

Hymes, D. (1974). Foundations in sociolinguistics: An ethnographic approach. Philadelphia: University of Pennsylvania Press.

Jakobson, R. (1960). "Closing statement: Linguistics and poetics." In T. Sebeok (Ed.), Style in language: Essays on the language of literature, (pp. 350377). Cambridge, MA: MIT Press.

Jones, R.F. (1953). The triumph of the English language: A survey of opinions concerning the vernacular from the introduction of printing to the Restoration. Stanford, CA: Stanford University Press.

Kilgore, D. (1981). "Moby-Dick: A whale of a handbook for technical writing teachers." Journal of Technical Writing and Communication, 11, 209-216. 
Labov, W. (1972). Sociolinguistic patterns. Philadelphia: University of Pennsylvania Press.

Lerner, M. (1957). America as a civilization. New York: Simon and Schuster.

Lipson, C.S. (1985). "Francis Bacon and plain scientific prose: A reexamination." Journal of Technical Writing and Communication, 15, 143155.

Lovejoy, A.O. (1936). “The study of the history of ideas." The Great Chain of Being, (pp. 3-23). Cambridge, MA: Harvard University Press.

Mann, C.R. (1918). A study of engineering education. (Bulletin No. 11). Carnegie Foundation for the Advancement of Teaching.

Marcus, A.I., and Segal, H.P. (1989). Technology in America: A brief history. San Diego: Harcourt Brace Jovanovich.

May, H.F. (1964). The end of innocence: $A$ study of the first years of our own time 1912-1917. Chicago: Quadrangle Books.

$\star \star$ McDonald, P.B. (1929). English and science. New York: D. Van Nostrand Company.

Merritt, R.H. (1969). Engineering in American society 1850-1875. Lexington, KY: University Press of Kentucky.

Miller, C. (1979). "A humanistic rationale for technical writing." College English, 40, 610-617.

Moran, M.G. (1985). The history of technical and scientific writing. In M. G. Moran and D. Journet (Eds.), Research in Technical Communication: A Bibliographic Sourcebook, (pp. 25-38). Westport, CT: Greenwood Press.

$\star \star N a e t h e r$, C.A., and Richardson, G.F. (1930). A course in English for engineers. Vol. 1: The engineer's speaking and writing —ingeneral. Boston: Ginn and Company.

Nichols, M. (1991). “Thomas Jefferson's Notes.” Technical Communication, 38, 149-150.

Olson, D.R. (1977). "From utterance to text: The bias of language in speech and writing." Harvard Educational Review, 47, 257-281.

Ostrander, G. (1970). American civilization in the first machine age: 1908-1940.

New York: Harper and Row. 
Park, C.W. (1926). English applied in technical writing. New York: F.S. Crofts and Co.

Poulsen, M.R. (1990). "Hemingway's style and the technical communicator." Technical Communication, 37, 341.

Price, A. (1988). "David Bushnell: An inventor describes his invention." Technical Communication, 35, 344.

Reddy, M. (1979). "The conduit metaphor-A case of frame conflict in our language about language." In A. Ortony (Ed.), Metaphor and thought, (pp. 284-324). New York: Cambridge University Press.

Richardson, H.C., Becklund, L.N., Guthrie, L.O., and Haga, C.I. (1934). Practical forms in exposition: A manual designed to assist technical students with papers, letters, reports, and reading. New York: Macmillan.

Rickard, T.A. (1908). A guide to technical writing. San Francisco: Mining and Scientific Press.

$\star \star$ Rickard, T.A. (1920). Technical writing. New York: John Wiley and Sons.

Rivers, W.E. (1994). "Studies in the history of business and technical writing: A bibliographic essay." Journal of Business and Technical Communication, 8, 6-57.

Rubens, P.M. (1985). Technical and scientific writing and the humanities. In M.G. Moran and D. Journet (Eds.), Research in Technical Communication: $A$ Bibliographic Sourcebook., (pp. 3-23). Westport, CT: Greenwood Press.

Rutter, R. (1991). "History, rhetoric, and humanism: Toward a more comprehensive definition of technical communication." Journal of Technical Writing and Communication, 21, 133-153.

Schmelzer, R.W. (1977). “The first textbook on technical writing." Journal of Technical Writing and Communication, 7, 51-54.

Schulman, J. (1963). "Cotton Mather, America's first technical writer." STWP Review, 10(April), 20-22.

Smith, N.V. (Ed.). (1982). Mutual knowledge. London and New York: Academic Press.

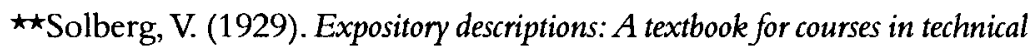
writing. New York: The Ronald Press. 
Spencer, H. (1878). “The philosophy of style." Essays: Moral, Political and Esthetic, (New and enlarged ed., pp. 1-47). New York: D. Appleton.

Tebeaux, E. (1981). "Franklin's Autobiography-important lessons in tone, syntax, and persona." Joumal of Technical Writing and Communication, 11, $341-49$.

Tebeaux, E., and Killingsworth, M.J. (1992). "Expanding and redirecting historical research in technical writing: In search of our past." Technical Communication Quarterly, 35, 196-207.

Trelease, S.F., and Yule, E.S. (1925). Preparation of scientific and technical papers. Baltimore: Williams and Wilkins Company.

Waddell, J.A.L., and Harrington, J.L. (1912). Addresses to engineering students. Kansas City: Waddell and Harrington.

$\star \star$ Watt, H.A., and McDonald, P.B. (1925). The composition of technical papers. (2nd ed.). New York: McGraw-Hill.

White, M.G. (1952). Social thought in America: The revolt against formalism. New York: Viking Press.

Wickenden, W.E. (1930). Report of the investigation of engineering education 19231929. Lancaster, PA: Society for the Promotion of Engineering Education.

John Hagge (associate professor, English and Program in Linguistics, Iowa State University) has published in Journal of Advanced Composition, Journal of Business Communication, Journal of Business and Technical Communication, Journal of Technical Writing and Communication, Management Communication Quarterly, and Written Communication (among other). He has worked as a technical writer/editor and taught courses on technical editing and business communication; currently he teaches linguistics and the history of the English language. He has won a 1988 Alpha Kappa Psi Foundation Award for Distinguished Publication in Business Communication and a 1990 Iowa State University Teaching Excellence Award. 
